\title{
Urban and architectural reuse of the former Chapingo Hacienda: sustainable criteria for the conservation of built heritage
}

\author{
F. J. Soria, F. H. Alfaro \& C. A. Limones \\ Universidad Autónoma Metropolitana-Xochimilco in México City, \\ Cuerpo Académico en Conservación y Reutilización del Patrimonio \\ Edificado, Mexico
}

\begin{abstract}
Nowadays there is no denying the existing affinity between the concepts aimed to preserve built heritage and the principles of environmental sustainability that seek the conservation of the natural surroundings. They are, in fact, fields that have a common goal: to maintain a legacy that we have inherited and we have the responsibility to safeguard for future generations, in the best conditions of authenticity and with the least possible alterations. It is in our nature, as human beings, to transform the surrounding environment in order to generate a new living space, driven by our material and spiritual needs, action that causes enormous changes in the natural environment, making it increasingly artificial. Therefore, nature and artifice (or culture) should not be considered extremes, more likely, they are two sides of the same coin, anchored in contemporary society which is caught in a permanent debate between heritage conservation and simultaneously achieving better levels of human development.

The case of the former Chapingo hacienda, - currently the main campus of the Autonomous University of Chapingo (UACH) - is representative of how sustainability and heritage conservation can go hand in hand. On one side, the campus of the university is settled in an old hacienda built in colonial times, that was reused in the 1920s to accommodate the National College of Agriculture, which in the 85 years of life there, has accumulated an extraordinary built heritage, which includes buildings of the $18^{\text {th }}, 19^{\text {th }}$ and $20^{\text {th }}$ centuries of great historical, aesthetic and symbolic value, that have an inadequate condition of conservation. On the other side, the natural elements on the site are in an accelerated process of destruction and loss caused by an uncontrollable urban
\end{abstract}


sprawl of Mexico's metropolitan area. If we consider that the UACH is an agricultural university, that implies the management and control of natural resources such as water, soil, forest or the handling of livestock, the conservation of these traditional buildings and the sustainability of the natural surroundings is a major compromise.

Keywords: built heritage reuse, environmental sustainability, heritage conservation, sustainable conservation, adaptive reuse.

\section{Introduction}

Due to the negative environmental impact inflicted by the overflowing urban growth in the area and to the systematical deterioration of built heritage of the UACH campus, the authorities considered urgent to undertake a project to assess and propose a reorganization of the site directed to urban and architectural revitalization in order to conserve, simultaneously, the cultural built heritage and the natural resources of this unique place.

A detailed investigation allowed documenting, analyzing and establishing the natural and cultural values and assets of the campus, which gave way to embrace a series of sustainable design guides aimed to guarantee the safeguarding of this important heritage. The main goal was to enhance the functional conditions, organize future urban growth, reuse architectural heritage, minimize ecological impacts of new buildings, preserve all natural resources, in other words, integrate architecture, nature and education to generate a harmonic and sustainable environment.

In the past three decades, the concept of sustainability has permeated modern society in almost all aspects, that is, in political, educational, economic, cultural and even in legal terms. However, its application or general daily practice is far from happening. Where does the need for change in attitude towards our natural and cultural heritage come from?

There is no doubt that concern to preserve what we consider important, meaningful and necessary is not a new practice, although its formal implementation, systematic, professional and social commitment is certainly a modern concept. The common denominator appears largely when society realizes that significant components of its known surroundings gradually disappear, get destroyed or simply are forgotten; in other words, the action or inaction of mankind can change, deteriorate or eventually destroy the living environment. This general affection on the city, buildings, plants, animals, atmosphere, on the environment as a whole means, in the long run, an impact on ourselves, as individuals and as a society; therefore the need to recognize the problem in order to propose actions to reverse, or at least, to slow down this process of progressive destruction.

The philosophical view of conservation and restoration of cultural heritage begins its theoretical and methodological proposals mainly during the $19^{\text {th }}$ century due to several reasons, as were the destruction caused by political, religious or military conflicts; the looting that colonialism of other countries permitted; the impact of urban sprawl triggered by the industrial revolution, 
among others. During the twentieth century a major boost towards heritage conservation as a global task, comes as a reaction to the destruction that world wars caused on cultural property. In this 'international' responsibility context, new agreements involving several countries were gradually generated, duty that increased significantly since the 1960 s with the appearance of major specialized documents, conventions and guidelines in this field.

Another approach initiated in the twentieth century has been that of environmental sustainability, mainly since the 1950s "...as we become aware how human action and production are progressively devastating the natural environment..." [1]: air pollution, oil spills, the consequences of pesticide use, nuclear accidents, overpopulation, just to mention the best known. The work and meeting of specialists as well as the acceptance by the international community of the need to undertake joint actions increases in time and is translated into world events (Rio 92, Kyoto Protocol or Johannesburg 2002 for example) in order to establish certain commitments.

Both heritage conservation and environmental sustainability are about survival of common good and are recognized as essential for society, even when they have developed in parallel and somewhat independent ways. Probably one of the main achievements on this respect was the Convention Concerning the Protection of the World Cultural and Natural Heritage celebrated by UNESCO in 1972 where "The most significant feature of the 1972 World Heritage Convention is that it links together in a single document the concepts of nature conservation and the preservation of cultural properties. The Convention recognizes the way in which people interact with nature, and the fundamental need to preserve the balance between the two" [2]; unfortunately this integrated (sustainable without doubt) vision was postponed leading afterwards, probably until the late 1990s, to specialized and separate treatment of nature and culture.

More recently, the concern for preserving cultural heritage and the natural environment has evolved from a selective and biased approach to a wider and inclusive stance, open to various interpretations, taking a "...shift in focus from buildings and monuments towards the wider historic environment. While this was undoubtedly strongly influenced by thinking in the natural environment, which over the same period saw a shift from species conservation towards habitat conservation, onwards to landscape scale approaches..." [3].

Now days there is an increasing recognition of the need to address issues of cultural heritage safeguarding and natural environment preservation under a sustainable perspective, that is a holistic approach open to dialogue and diverse interpretations in a collective sense.

Cultural heritage, like most natural resources, are non-renewable assets that cannot be replaced, for they are unique and unrepeatable, generated in a given time and space that are impossible to reproduce. There are limits that we must understand in the way we use and take advantage of our surroundings: "The historic environment, like the natural environment, can only accommodate a certain level of activity, or ratio of change, before it is damaged permanently and loses its character and value" [4]. 
The main goal is to protect and preserve our natural and cultural environments, as a means to achieve the objective of sustainability: wellbeing and quality of life for today's society and, at the same time, to safeguard this heritage as a right for future generations. This is the common task, the point of encounter between heritage conservation and environmental sustainability, concepts that should be integrated as a permanent way to think when we intervene on our surrounding context.

\section{Background of the former Chapingo Hacienda}

In the late seventeenth century the Society of Jesus purchased the estates of Our Lady of the Conception, Our Lady of Solitude and Saint Bernard of Huexotla and Saint Paul Nativitas all in the setting of Texcoco (in the present State of México) to the Marquis Francis of Medina, a Knight of the Order of Santiago and treasurer of the Royal Mint. This religious Order joined all those properties and consolidated an important Hacienda (a form of property of large territories used for agricultural activities since colonial times in New Spain and in latter independent México) called: "Our Lady of The Conception of Chapingo" [5, 6]. The existing infrastructure was then limited to a fuller and some fields to make way for water in order to irrigate the land. When the Society of Jesus owned the property during 68 years (they kept it from 1699 to 1767) many important transformations were made: The main house (two stories high), the chapel and some barns to store wheat were built; the extension of the estate had an important growth, new infrastructure was incorporated, mainly for irrigation purposes and new crops were introduced.

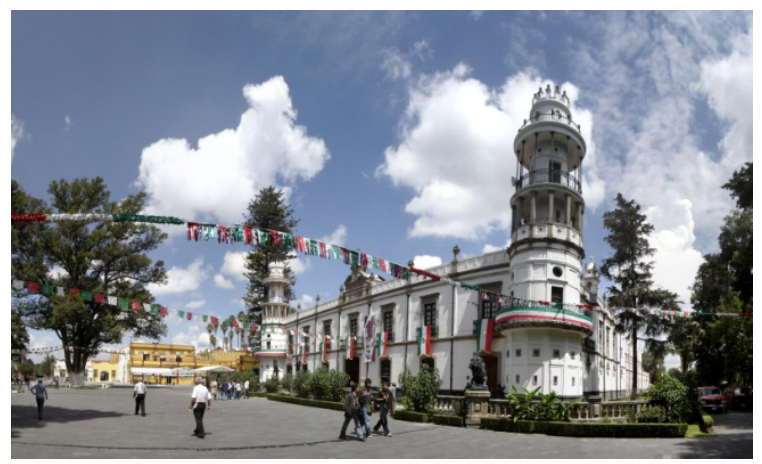

Figure 1: The main house of the old Hacienda. Today used as offices and museum.

When the Jesuits were expelled from New Spain and all their properties were seized, the Chapingo Hacienda was confiscated and expropriated during the period of 1767-1777, by the law of Estates of Temporality and during those years was under the care of an Interim Board of Alienation who leased the property. The hacienda was auctioned to Pedro de Codercha who kept it from 
1777 until 1786, when the property was reclaimed by the Board. Again the estate was auctioned, now to Don Antonio de Vivanco, whose family owned the hacienda during most of the nineteenth century for nearly 98 years.

During the 1880s General Manuel González (in that time President of México) purchases the Hacienda of Chapingo, and again the property had significant changes among which were the redesign of the main house with strong eclectic features, as well as the construction of a branch of the interoceanic railroad that went from México City to the city of Veracruz in the Gulf of México, one of the most important ports where Mexican products were exported towards Europe. Also the estate had a new territorial growth, together with the introduction of modern plows, threshing machines, steam-driven threshers, besides enhancing the fecundity of the land trough fertilizers and irrigation infrastructure. As far as livestock was concerned, fine cattle was introduced in 1884; the construction of the Port of Chapingo, a warehouse located in México City. By 1885 the telegraph line was introduced from México to Tecate through Chapingo, which also communicated to the city of Texcoco.

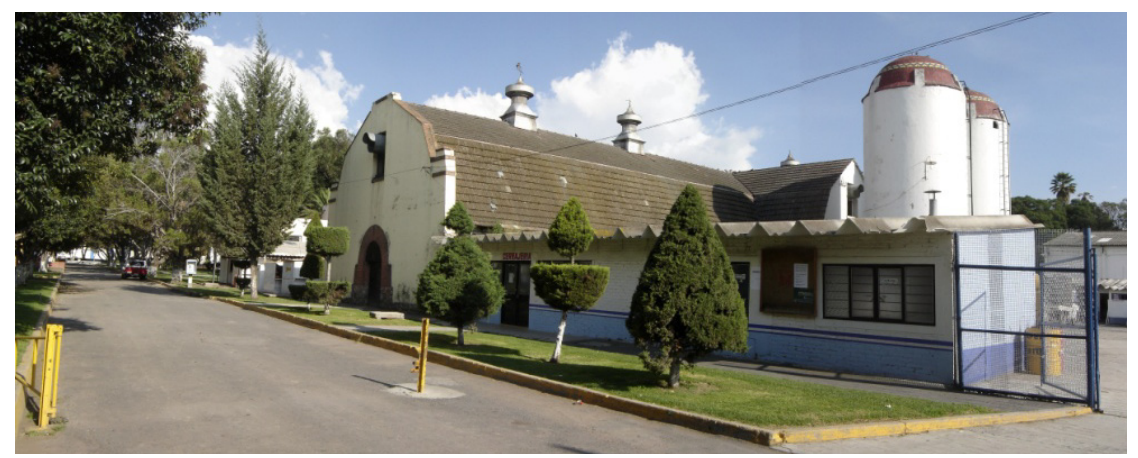

Figure 2: View of the stables built in the late 1920s when the ENA is moved to Chapingo.

At the beginning of the twentieth century, with the social changes triggered by the Mexican revolution, the Chapingo Hacienda was seized by order of Venustiano Carranza with the purpose to use it as the National School of Agriculture; idea that was later confirmed with the decree of expropriation appeared in the official newspaper the $22^{\text {nd }}$ June 1923. It would be President Alvaro Obregon who finally implemented the expropriation process on the grounds of public interest. The former hacienda's facilities were then remodeled to house the National School of Agriculture (ENA).

The National School of Agriculture and Veterinary (ENAV) had started its history in 1843, formalizing its existence in 1845; but it is until February 22 of 1854 when the idea of having a center of formal education in the fields of agriculture and livestock breeding becomes a reality, when the school was inaugurated in the former convent of San Jacinto in México City.

For the transfer of the ENAV to Chapingo the government took into account a number of factors: climate conditions, irrigation facilities, its proximity and 
quick communication with México City, the quality of the land, the existence of fine cattle, as well as the technological advances introduced in the productive process of the estate. With no doubt General González and his family as owners of Chapingo (to whom the property was expropriated) brought great benefit to the hacienda, advantages that were well used by the heirs of the Mexican Revolution.

The first opening of the ENA Chapingo was eminently symbolic and was celebrated on October 4 1921. The idea was to formalize the willingness to use the seized property of the González family, giving it a high social sense and to aim its use towards the specialized training of people in the productive activities of land. Prior to its arrival to Chapingo in 1923, the ENA modified its study programs in 1920, establishing the career of Agronomist Engineer, with the specialization in Agriculture, Livestock, Irrigation and Agricultural Services and Industries. The refurbishment works were still far from being finished, so the opening of the ENA in the former Chapingo Hacienda, really took place on May 1, 1924. An important fact of this institutional and territorial symbiosis was marked by the presence of painter Diego Rivera, whom through his artistic work embodies the revolutionary ideology of the time on the walls and buildings of the ENA.

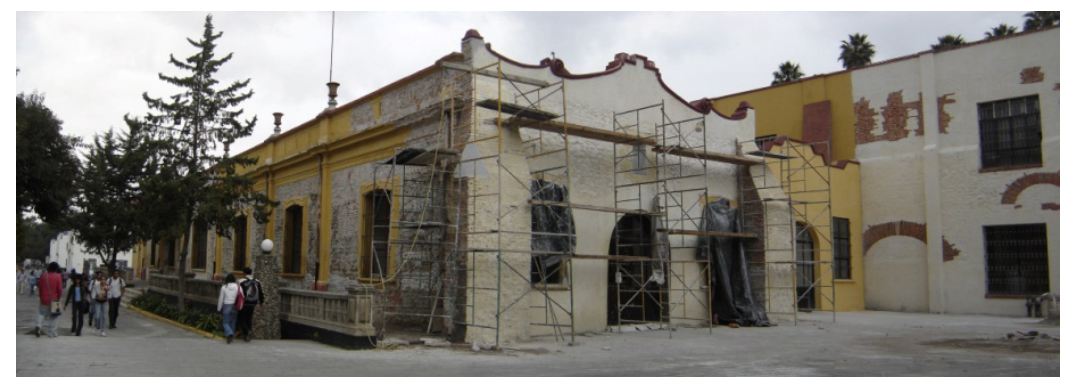

Figure 3: $\quad$ Restoration of $18^{\text {th }}$ century warehouses of the hacienda.

The ENA used the preexisting buildings of the former hacienda, which were adapted to perform new functions; the main building was reconditioned as offices and classrooms; the barns and warehouses are adapted as bedrooms and services for students. The construction of new buildings was also undertaken, to meet the demands of the new purpose: library, study hall, modern barns, horse stables, piggeries and some silos. For teachers and staff of the new school, the 'Ramón P. Denegri' cooperative town was built. In 1945 due to the $100^{\text {th }}$ anniversary of the first founding of the ENA, various projects in benefit of the students were made, including 5 residential pavilions (the capacity of the facilities reached 1000 students with room and board), dining room, laundry room, and sports facilities.

By the early 1960s the school pursued the consolidation and integration of all activities related to education, agricultural research and dissemination in a same direction. Endowed with an important budget coming from the federal government as well as foreign foundations, on February 221963 the Chapingo 
Plan was announced. Taking advantage of economic and political stability, virtually all the school's infrastructure is modernized; postgraduate studies and agricultural research are strongly promoted. This new phase is inaugurated on February 22 of 1967. The Chapingo Plan renovates the image of the school giving it a modern appearance with the construction of new buildings and the campus is consolidated through a new peripheral road circuit in an attempt to organize and limit urban growth of the ENA. Many features and material traces of the old hacienda are inevitably erased.

In the early 1970 s the federal government reformulated agricultural and agrarian policies in an attempt to recover growth and productivity of the country's farmland. In this context, the Chapingo Plan is abandoned and the proposal seeks to merge, in a new university, the National School of Agriculture and the College of Postgraduates that had been working separately. Congress approves the Law that creates the Autonomous University of Chapingo (UACH) on December the 30 1974, that gives way to new buildings that aim not only to solve specific needs, but also to generate a new institutional image.

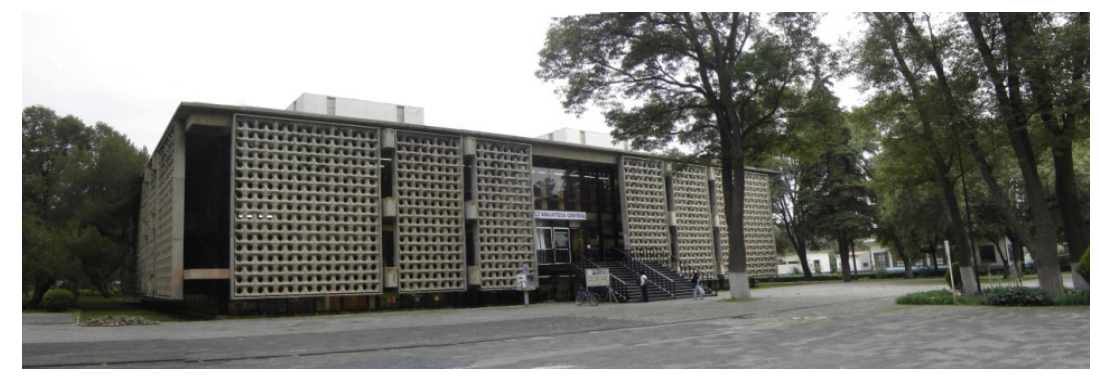

Figure 4: The 'new' library built in the 1960s as part of the Chapingo plan.

Since the 1990s the UACH has undertaken a serious review and modification of all its study programs which has resulted in changes in many graduate programs, the creation of new careers as well as other postgraduate studies, with important and recognized research and community service programs that support the institutional relations with outer social actors. This has resulted in the appearance of new buildings that have responded more to pressures and haste of time, rather than to strategic or coordinated actions.

\section{Decline and loss of cultural heritage on campus}

The campus of the Autonomous University of Chapingo is today a place of enormous environmental, urban and architectural richness and interest, which has acquired over time a distinctive character, probably unique on a national level, as a center of higher education. By reusing the old hacienda, the National School of Agriculture, not only took advantage of the existing buildings, it also incorporated and provided new elements to design a proper space for its teaching activities, beginning in this way a constant process of stratification of constructive stages. 
Unfortunately, in the past three decades the chaotic urban sprawl as well as the lack of a broad conservation and development plan for the campus has generated an important environmental, urban and architectural deterioration process that has put this extraordinary built heritage at risk. In an attempt to reverse this situation in 2008 the UACH undertook the task to elaborate a proposal that could reorganize and rescue the campus as a whole. For this purpose the UACH relied on the expertise of the Academic Group on Conservation and Reuse of Built Heritage (CACRPE) of the Autonomous Metropolitan University, Xochimilco Campus, in order to develop a detailed analysis, assessment and diagnosis of the current physical and environmental conditions of the central Campus and from there, design a holistic project to rescue the former Chapingo hacienda. It is important to point out that the implementation of an environmental, urban and architectural conservation and development plan for the UACH central campus is part of a wider vision included in the Institutional Development Plan 2009-2025 [7], where an emphasize has been made on the existing environmental problems and the need for a sustainable development of the university.

The main problems that were identified during the analysis as affecting the natural surroundings, built heritage as well as the inner functionality of the campus were the following:

Environment: The excessive and uncontrolled urban growth of Mexico City's Metropolitan area, of which the municipality Texcoco is part, has radically transformed the natural and artificial settings of the UACH over the past four decades. This phenomenon has impacted all areas that is, soil, water bodies, plants, wildlife, and of course built heritage. This has led to a series of serious environmental problems such as air pollution, water contamination, loss of green fields, soil contamination, and deforestation, among others.

Land use: An important dispersion of the different academic areas was detected; that is, from a certain grouping order by 'specialties' or academic departments in the same zones and even in specific buildings, in recent years the occupancy pattern tendency is completely random, generating unordered facilities as well as considerable distance between sites that should be together. There is a huge inefficient use of most physical spaces on campus that goes from unused, closed or underused areas, to overcrowded zones, where functions, users, cars, street furniture are literally overlapped. This implies a considerable imbalance in spatial distribution.

Roadways: Vehicular circulations have grown considerably within the peripheral circuit, invading many central areas of campus that were once for pedestrian use. The increase of car use has led to the quick implementation of new roads and parking lots within the campus that have not been planned, which represents problems of insufficient space, low functionality, loss of security and of course a negative impact on urban image as a whole.

Maintenance and upgrading of infrastructure and services: The UACH does not have a program of constant, systematic and planned maintenance for open spaces, buildings and infrastructure of the campus as a whole or its technological 
upgrading. Most of the infrastructure networks are obsolete and no longer meet current standards implying a high energy cost for the university.

Urban image: The uncontrolled construction of many small buildings (sheds, warehouses, workshops and even small businesses) as well as the implementation of car parking on roadways, sidewalks and plazas has become a land use pattern. Apparently these buildings by their size have no impact on land use, but their contribution to deteriorate urban image is very important. Their design is almost always thought as a 'provisional' element that obeys to time and economic considerations and not to dialogue and integration criteria with the existing urban and architectural characteristics of the UACH campus.

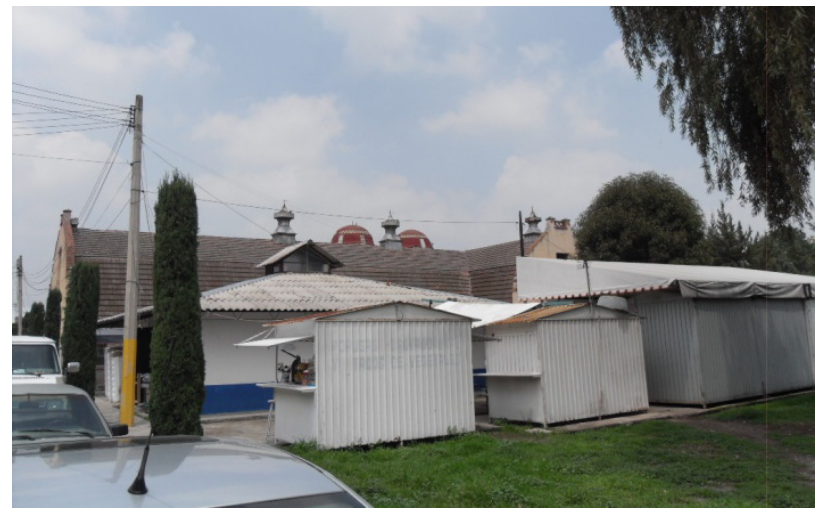

Figure 5: The uncontrolled building of 'temporary' sheds and workshops has had a negative impact on urban image.

Buildings and places of heritage value: Many heritage buildings have incorporated incompatible uses or have been improperly adapted, which has resulted in an important degradation process and underuse of these properties. Also many old constructions have been eliminated as is the case of the perimeter wall of the old hacienda.

New buildings: Construction of new buildings, open spaces and infrastructure (for the past 30 years) is not regulated in terms of urban and architectural values of Chapingo. The low considerations and even the ignorance of the contextual characteristics of the campus have generated poorly integrated buildings, disrupting the harmony and balance that was kept until the early 1970 s.

\section{Criteria for sustainable conservation of built heritage}

The diagnosis and assessment exercise developed by the CACRPE served as the basis to generate a proposal for the reorganization and recovery of the natural and cultural heritage of the UACH. The main criteria [8] to guide any future intervention on campus are the following:

- The UACH for its vocation as a higher education center in agricultural activities has a particular commitment with the conservation, wise use 
and respect for the natural environment. All the programs, projects and general activities carried out by the University in the planning, design, maintenance, construction, and operation of its facilities will be done invariably under environmental sustainability principles.

- Rearrangement of land and building use of the UACH is particularly important in order to generate the best conditions for a balanced urban and architectural development, an efficient internal operation, a harmonious urban image and to preserve the heritage characteristics of the ensemble.

- Create the necessary conditions in order for pedestrians and vehicles to move through campus with the best possible levels of safety, functionality, comfort and information, making the UACH a barrier-free facility for the academic community as well as visitors.

- Transform Chapingo Campus into an environmentally sustainable site as a fundamental part of their institutional identity, through the replacement and incorporation of low environmental impact infrastructure and buildings.

- Revert urban image degradation of Chapingo Campus through the systematic recovery of open spaces, green areas, as well as road and parking lot reorganization.

- Support the rescue, conservation, restoration and reuse of heritage places and buildings, preferably with the use of a collective nature.

- Promote the creation of normative instruments to regulate, monitor and advise design and construction of new buildings as well as the use of open spaces in order to restore and eventually maintain a harmonious urban image of campus.

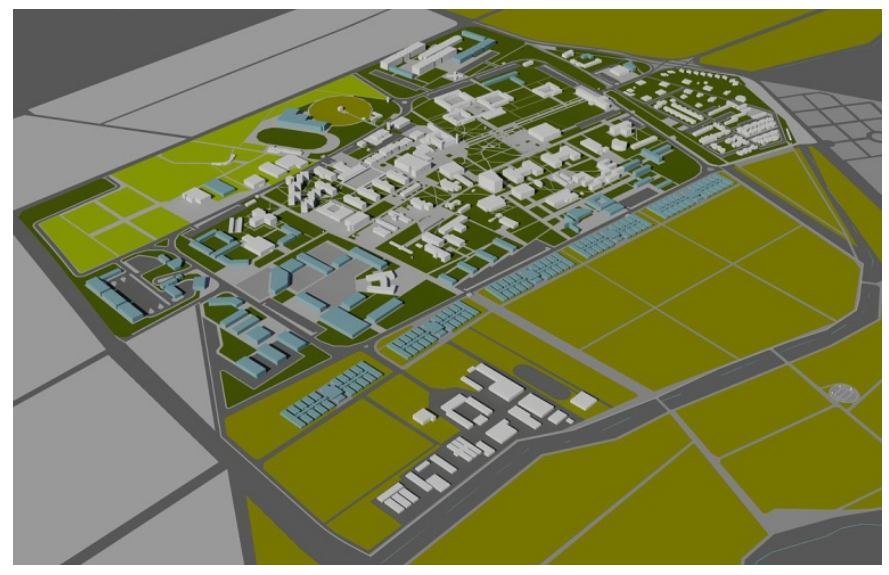

Figure 6: Virtual model of the urban master plan for the reorganization and proper reuse of Chapingo Campus. 


\section{Conclusions}

It is possible to establish that, as it happens in the city of today (and also in many university campuses), there has been a lack of plans that could be capable of orientating towards a common objective, the actions that influence the formation of physical space, which has produced intense and progressive deterioration of the University City. This daily process has created negative behavior patterns among their actors, who try to solve problems, sometimes real, driven by immediacy and ignoring the great cultural value of the architecture they act on. However, it is essential that the university community understands and appreciates this heritage because if they do not participate actively in its protection and preservation, no plan can succeed [9].

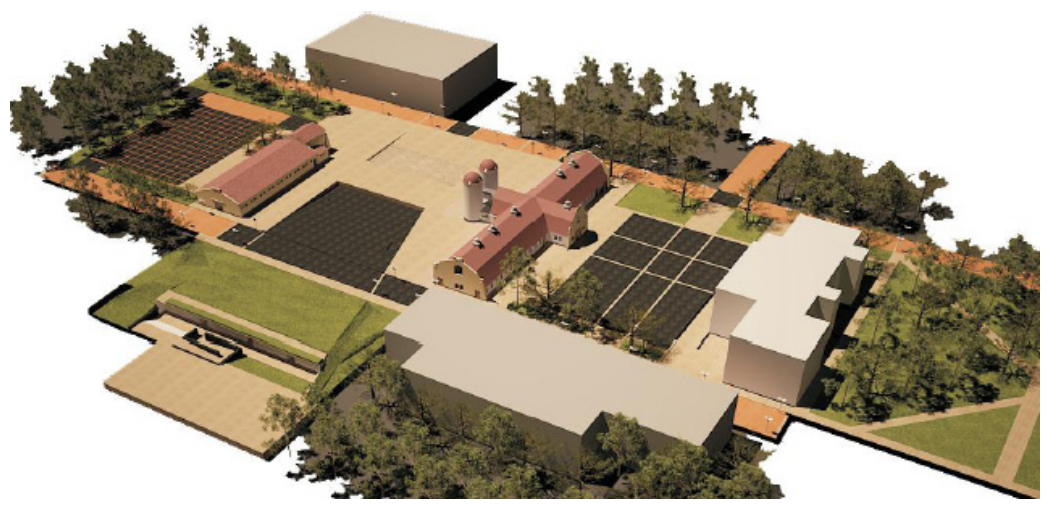

Figure 7: The plan proposes the reuse of significant buildings as well as the recovery of open spaces.

The problems of conservation and rescue of cultural and natural heritage should therefore be undertaken in a holistic manner, based on social, economic and environmental sustainability criteria, never with an isolated vision, no matter how highly specialized it could be. The proposal made by the master plan for urban and heritage reorganization of the Chapingo Campus is, in any case, a part of a much broader view that the University is trying to carry out (through its Institutional Development Plan 2009-2025) with the participation of all its community, as the only way to improve not only the teaching, research and cultural dissemination processes, but also the preservation of its natural and cultural heritage that is a fundamental part of Chapingo's identity.

It is obviously necessary to review very carefully the criteria used to define value, preservation policies and proper use of the different buildings that are relevant to the history of the UACH campus. The assets and value of the ensemble are not only in those constructions, but also in the open spaces, environmental aspects of its green areas, water bodies, farmlands, as well as in the sense of resistance to the surrounding urban sprawl, that all together give this context a definition as a unique built heritage that should be considered in all its dimensions. 
Therefore the master plan intends that the central campus becomes not only into a functional and pleasing heritage place for the community, but also in a representative way of what sustainability means in the field of architecture: where appropriate reuse of the built and open spaces that preserve and give meaning to the history and identity of the institution will contribute to reduce environmental impact, by increasing the lifecycle of heritage buildings, reducing the incorporation of new constructions, and when these must be integrated, they will be designed with environmentally friendly materials and infrastructure. The plan strongly promotes the recovery and preservation of natural elements of the campus through the enhancement of the value of green areas, water bodies, and farmland and very importantly seeks to restore pedestrian priority in the use of open spaces.

The former Chapingo Hacienda, today home of the Autonomous University of Chapingo is a unique urban, architectural, artistic and environmental heritage of México, which brings together in a same campus, a great building diversity with a natural environment that need to be conserved in a sustainable way, in order to create a high quality living space for the present community and simultaneously ensure its preservation for future generations.

\section{References}

[1] Soria López, F.J., Architecture and nature at the end of the 20th century: towards a dialogical approach for sustainable design in architecture, in Eco-architecture. Harmonisation between architecture and nature; WIT press Wessex Institute of Technology, Southampton, 2006. p. 23-23

[2] UNESCO, The World Heritage Convention; consulted 25 April 2011 at http://whc.unesco.org/en/convention/

[3] Thérond, Daniel (2009), Benefits and innovations of the Council of Europe Framework Convention on the Value of Cultural Heritage for Society; in Heritage and beyond, Council of Europe Publishing, Strasbourg, 2009; p. 13-21.

[4] Lancashire County Council, Part I - Sustainability and the Historic Environment; consulted 10 December 2010 at: http://www.lancashire.gov.uk/corporate/web/?Archaeology_Heritage/20424

[5] Anaya Pérez, Marco Antonio et al. Ciento cincuenta años en una mirada. Universidad Autónoma Chapingo. México, 2004.

[6] González Marín, Silvia. Historia de la Hacienda de Chapingo. 2a . Reimpresión. Universidad Autónoma Chapingo. México, 2001.

[7] Universidad Autónoma Chapingo; Plan de desarrollo Institucional. 20092025. Documento consultado el 25 de enero de 2011 en: http://portal.chapingo.mx/contenidos/content/view/68/2/

[8] Cuerpo Académico en Conservación y Reutilización del Patrimonio Edificado; Documentos de trabajo para el Proyecto de Plan Rector.

[9] Plan Rector para el campus de la Universidad Central de Venezuela, 1999. Author's own translation; consulted 10 June 2009; see text in Spanish at: www.ucv.ve/villanueva/nuevadata/ciudad/plan 